pp. $554-568$

\title{
Effect of Transformational Leadership and Breakthrough Leadership on Organizational Performance through the Variable of Employee Satisfaction: A Case Study
}

Submitted 14/04/20, $1^{\text {st }}$ revision $19 / 05 / 20,2^{\text {nd }}$ revision $17 / 06 / 20$, accepted 15/08/20

\author{
Joko Triraharjo, ${ }^{1}$ Havidz Aima, ${ }^{2}$ Achmad Sutawijaya, ${ }^{3}$
}

Ahmad Badawy Saluy ${ }^{4}$

Abstract:

Purpose: The article investigates the impact of transformational leadership and breakthrough leadership on organizational performance both directly and through intervening variables.

Design/ Methodology/Approach: This type of research is a quantitative method. Primary data were obtained from questionnaires distributed while secondary data were obtained from a company's annual reports published. Respondents are employees of 15 coal mining companies listed in Indonesia stock exchange with a total of 201 samples from supervisors to directors. The data collected are analyzed using the SEM-AMOS (Structural Equation Model-Analysis of Moment Structures) at that point for the intervention impact by using the Sobel Test.

Findings: The findings of the study show that transformational leadership and breakthrough leadership both have a direct influence on employee motivation and satisfaction, but do not have a direct effect on organizational performance. Employees' satisfaction mediates breakthrough leadership on organizational performance.

Practical Implication: The study gives an input to the coal mining companies listed to improve organizational performance which requires a breakthrough leadership by fulfilling the requirements of employees' satisfaction. Priority fulfillment of employee satisfaction starts from fulfillment of need, discrepancies, value attainment, equity, and dispositional/genetic component.

Originality/Value: The research provides new concepts in the research framework and builds and enriches alternative dimensions of leadership breakthrough.

Keywords: Transformational leadership, breakthrough leadership, employee's motivation.

JEL Code: G20, G23, N20.

Paper Type: Research study.

\footnotetext{
${ }^{l}$ Corresponding author, Doctoral Management, Mercu Buana University, Meruya Selatan, Jakarta, Indonesia, e-mail: jokotri_ppa@yahoo.com

${ }^{2}$ Doctoral Management, Mercu Buana University, Meruya Selatan, Jakarta, Indonesia. e-mail: havidz.aima@yahoo.com

${ }^{3}$ Doctoral Management, Mercu Buana University, Meruya Selatan, Jakarta, Indonesia. e-mail: sutawijaya_69@hotmail.com

${ }^{4}$ Doctoral Management, Mercu Buana University, Meruya Selatan, Jakarta, Indonesia. e-mail: badawy_saluy@yahoo.com
} 


\section{Introduction}

The performance of coal mining companies in Indonesia listed has not significantly contributed to Indonesia's Gross Domestic Product (GDP) compared to Australia, Peru, Chile, or India. Resvani (2017) stated that the contribution of mining in the Australian Government's 2014 GDP was 8.9\%, in Peru 10\%, and in Chile 10\%. Five listed coal mining companies in Indonesia have recorded negative financial performance in the period 2013-2017. Explanation of the President Commissioner and the President Director of companies whose performance is still negative conveyed that leadership training was considered to increase the company's performance. A number of organizational performance theories suggest that differences in management determine organizational performance (Resvani, 2017).

The coal mining industry is a type of business with capital intensive (high capital), risk intensive (high risk) and technology intensive (high technology). Empirical facts state that some companies in the coal mining sector are successful but some are bankrupted. The results of a research for the prediction of bankruptcy of mining companies listed in the Indonesian stock exchange (IDX) in 2014-2016 showed that in 2014 the IDX-Listed mining companies in a dangerous zone were $62.5 \%$, grey zone were $20 \%$ and a safe zone were $17.5 \%$. In 2015 mining companies in the danger zone were $60 \%$, in the gray zone were $12.5 \%$ and in the safe zone were $27.5 \%$. In 2016, it was predicted that bankruptcy is $57.5 \%$, in a gray zone $15 \%$ and in a safe zone is $27.5 \%$ (Diratama, 2014). The signs of bankruptcy that management knows in advance is important because the management (the leaders) can improve performance more quickly so bankruptcy can be avoided (Sarwani and Sunardi, 2017).

The Decree of the Minister of Energy and Mineral Resources of Indonesia Number $1827 \mathrm{~K} / 30$ /MEM/2018 regarding guidelines for implementing good mining engineering principles in Attachment 1 provides guidelines for application, evaluation and/or ratification of the head of mining engineering, a person in charge of engineering and environment, head of underground mining, operational supervisor, technical supervisor and/or on operational responsibility. The Attachment to this decision states that leadership is important and mandatory because of the large responsibility runs by mining operations from a technical perspective and economic perspective.

The influence of leadership style on employee performance at PT. Loa Haur Energi (Mining Contractor) in the Payang Loa Kulu River, Kutai Kartanegara Regency East Kalimantan, Indonesia has a positive and significant relationship (Saputra, 2012). Research in coal mining at PTBA (PT Bukit Asam) shows that leadership has a positive effect on employee motivation and performance. The Coal Mining Exploitation Work Agreement (PKP2B) of PT Multi Harapan Utama is the first generation PKP2B which during the past management leadership, the amount of production in 2014, 2015 and 2016 was around 2,200,000 tons, but after a change of 
leadership, the total production in 2017 was 3,500,000 tons, in $20185,600,000$ tons and in 2019 9,200,000 tons (Resky and Kuncoro, 2012).

Success on that organizational performance is altogether affected by transformational leadership (Ugochukwu, 2014). Organizational performance is impacted by responsive transformational leadership (Katou, 2015). Multinational companies in Malaysia look at the relationship between leadership (transactional, transformational, authentic, spiritual) and company trade execution intervened by job satisfaction. It appeared that by interceding job satisfaction factor for the leadership style has impact on trade execution with the most elevated importance on spiritual leadership, then authentic, transactional and transformational leadership (Kader Ali and Tang, 2016).

Harvard Business Review on Breakthrough Leadership said that leaders must be in accordance with the leadership needed by the group, be wise, their words can be accepted and are able to think correctly even though there is a lot of pressure from anywhere (Gera, Vis and Michael, 2002). Development, plurality and disruption shown through VUCA, (volatile, uncertain, complex, and ambiguous), period in which the fundamental and very important activity is ready as a respond to the rapid changes in the organizational environment (Leksono, 2018).

The idea of breakthrough leadership was conveyed by the Harvard Business Review on Breakthrough Leadership (2001), American Management Association - AMA (2018) that breakthrough leadership consists of 5 dimensions, namely exemplary, extreme visionary, high standards for target, multi power leader and ability to care. Harvard Business School Publishing (2015) stated that a more effective leader is breakthrough leadership. The phenomenon of organizational discrepancies in coal mining companies in Indonesia (IDX-Listed) both from productivity and market sharing, referred to previous research studies and several performance theories, to improve organizational performance in VUCA and disruption situations breakthrough leadership is needed. Breakthrough leadership is used as a latent variable which is novelty in this study.

\subsection{Transformational Leadership (TRF)}

Leadership is doing what the pioneer needs to do. The leader is an agent of change who acts to impact others more than the activities of others influence him, the leader executes more than what is anticipated by his devotees. Leadership is divided into two kinds, transactional and transformational leadership. The characteristics of authority depend on the behavior, values, and ethics of person pioneers, leadership must be transformational to attain devotees' performance passed the regular limits. Superior leadership performance is transformational leadership (Bass, 1999). Effective and efficient leadership is transformational (Luthans and Doh, 2012). Transformational leadership encourages followers in achieving organizational targets (Tham and Marn, 2012). Transformational leadership has a positive and 
significant impact on employee motivation in Pakistan's accounting segment management (Aunjum, Abbas and Sajid, 2017).

Improving quality is the priority of strategy to be implemented. Transformational leadership improves workplace motivation in the public sector. Furthermore, transformational authorities have a positive and significant impact on motivation of staffs within the Kareem Food Safety Council of Papua Territory, Indonesia (Sappe et al., 2016). Transformational leadership in a neighborhood company in Vietnam has a positive and noteworthy impact on employee satisfaction ( $\mathrm{Vu}$, Ho and Dinh, 2016). Several companies in Bosnia Herzegovina, and Germany also conveyed a higher correlation of DINC's transformative leadership than other leadership styles to employee satisfaction (Mujkić, 2014).

The transformational leadership with a critical impact on Kenya's organizational efficiency and Aswan as shown in a study by Amin (2016), proved a positive and significant effect of transformational leadership on organizational performance in SMEs in Bali, Indonesia. A specially-developed influence, inspiring motivation, intellectual stimulation, individualized consideration, are considered to be aspects of transformational leadership (Anas Al Haj, 2017).

\subsection{Breakthrough Leadership (BRT)}

The American Management Association (2018) divided the dimensions of the breakthrough leadership into five parts. To begin with driving individuals by case and being straightforwardly included, breakthrough leaders lead individuals, not companies. They realize that driving, persuading, and preparing is around individuals and not around the organization. The second is carrying out the main vision. Breakthrough leader knows that the vision does not exist within the far-off future. Vision is where you come from each day. That is the way you think, and how you act. Living a vision implies making a ponder exertion to realize current objectives and bring long term to the show. Third continuously raising standards, breakthrough leadership sets exceptionally tall benchmarks for themselves. They get it that they must be requested more from themselves than from their devotees. Fourth is being able to lead, organize and direct, breakthrough pioneers have three parts as pioneers, supervisors, and coaches. Fifth is making a new leader. Breakthrough leaders make more pioneers, not devotees. The company's breakthrough requires individuals at each level who can lead in line with the company's vision. Making leaders requires several openness and certainty from the leader of the breakthrough.

The Leadership Psychology in Australia, (2009) stated that breakthrough leaders are clearly characterized by six behaviors. First, appearing honest to goodness intrigued within the improvement of all individuals. The accentuation is on veritable intrigued. This implies taking the time to construct a more profound proficient with each person and do this truly. Second is tuning in to individuals and inquiring their 
thoughts. This appears regard for the individual and a conviction that they have something of esteem to contribute. This appears that the pioneer does not continuously have all the answers to all questions but is prepared to listen to the contemplations and concepts of others. Third is acting on the counsel of adherents. Follow-up exhortation ought to not be taken after up but sufficient on imperative and critical recommendations. When individuals see the effect of their thoughts around comes about, they have a more noteworthy esteem on the choices taken. This can be the primary step towards strengthening where the person steadily gets more impact, tolerating more prominent responsibility will donate superior comes about. Fourth is building challenges for people and appearing certainty in their capacity to provide. This ought to be a great presentation to everybody, understanding the agreement between commerce and individual objectives and accurately surveying capacities and learning from the individual concerned. The fifth is support and training. Leaders must give bolster by putting security nets that can deliver people the strength to step out of conventional considering and cultivate the improvement required to ace modern aptitudes. The sixth is giving feedback and acknowledgment. Criticism and acknowledgment are vital components in building connections since of adherents of the pioneer. Dynamic and valuable engagement with these pioneers not as it were builds capacity but too contributes to building self-esteem within the person concerned.

Compelling leaders are through breakthrough pioneers (Goleman et al., 2001). Breakaway authority gives a modern point of view, breakthrough leadership has numerous thoughts to assist create devotees and make strides the mentoring prepared (Schofield, 2015). The organized created by breakthrough leaders is exceptionally profitable (Jimad et al., 2020). Compelling and noteworthy leaders are breakthrough leadership through employee satisfaction mediators (Triraharjo, Aima and Sutawijaya, 2019).

\subsection{Employee Motivation (EM)}

Starting from strong desires and impulses on a person or organization influenced by the environment, it causes pressure on the person or organization. This pressure is supported by the presence of opportunities, targets, and stimuli to foster hard efforts to achieve the expected performance. Strong business is supported by the ability of a person or organization to produce good performance. The good performance will give satisfaction to the person or organization. Good performance also yields rewards that have an impact on employee satisfaction (Newstrom, 2014). Motivation could be a handle that takes into consideration the escalated, course and tirelessness of person endeavors towards the accomplishment of objectives (Robbins and Judge, 2003). Motivation is by and large related to person objectives whereas organizational objectives center on work-related behavior. Motivation may be a quality in somebody who has the heading, escalated, and diligence of deliberate behavior (Dowling and Pfeffer, 1975). Motivation could be a mental preparation that 
stimulates, coordinates and diligence in taking deliberate activities coordinated towards accomplishing objectives (Joshi, Joshi and Joshi, 2009).

Motivation techniques have a noteworthy relationship with organizational performance within the FOBETO industry in Nigeria (Akinola et al., 2014). It appears to have a connection between employee motivation and organizational performance in the organization. The study reveals that outward motivation given to specialists in an organization includes a critical impact on specialist performance (Emeka, Amaka and Ejim, 2015). Verbalizing the progress made in recognizing the motivation of employees and the organizational performance would inspire employees and improve the company's success (Lee and Raschke, 2016). Transformational leadership is essentially related to employee motivation within the Punjab Communication Sector (Ahmad et al., 2014). As Bank Batangas India Branch Manager said transition leadership has vital effect on employee satisfaction. Positive and critical relationship between the dimensions of transformation leadership and employee satisfaction at Bosnia-Herzegovina Private Universities (Rawat, 2015). Conveyed to a local company in Vietnam that transformation leadership has a positive, critical impact on employees' satisfaction ( $\mathrm{Vu}, \mathrm{Ho}$ and Dinh, 2016).

Dimensions and indicators used in this study are from Maslow, the selection of these dimensions is because the training material on motivation in the coal mining sector still uses Maslow's theory, these dimensions consist of physiological needs, safety and security needs, social needs the need for appreciation and the need for selfactualization (Newstrom, 2014).

\subsection{Employee Satisfaction (ES)}

Employee satisfaction has distinctive focuses of concurring to the seas of each master, most of these seas_are complementary in nature so that they can be clearly seen almost the employee's satisfaction. Employee satisfaction is the level of wonderful sentiments gotten from the evaluation of one's assignments or work involvement (Colquitt and Rodell, 2011), The job satisfaction is defined as a good feeling as an evaluation of its characteristics roughly functions (Robbins and Judge, 2003). Job satisfaction is as an assessment of someone's work. Implication employee satisfaction is not a single concept, as individuals can be fulfilled with one angle but there are moreover those who are disappointed with one perspective (McShane and Von Glinov, 2017)

Bukit Sanomas Company has passed on its inquiry into the significant and noteworthy effect on organizational success of staff satisfaction (Widjaja, 2016). The impact on organizational performance in Nigerian organizations between employee satisfaction has been shown in a study by Dugguh and Dennis (2014). Writing examination related to a few job satisfaction speculations such as emotional occasions, two variables, value and characteristics appears that a number of 
variables such as accomplishment, acknowledgment, obligation, compensation, working conditions and so on, have a positive impact of employee satisfaction on organizational performance.

Conducted a ponder at the Tulung Agung Sugar plant, East Java, Indonesia, expressing that $\mathrm{s}$ there was a positive and noteworthy impact between employee satisfaction variables on organizational performance (Sari, 2015). The employee satisfaction measurement concurring with payment, promotion satisfaction, supervisory satisfaction, satisfaction for work, altruism, status, and environment, while competing with employee satisfaction, discrepancies in value, equity, and disposable/genetic component (Calquitt et al., 2011).

\subsection{Organizational Performance (OP)}

Organizational performance is the capacity to get and prepare budgetary, physical, and human assets appropriately to realize organizational objectives. Organizational performance could be an item of interaction between different divisions and segments inside the organization which incorporates budgetary and non-financial measurements, financial scale is for the most part based on money related articulation information (Hamdam, Pakdel and Soheili, 2012). Non-financial pointers includes the following, the fulfillment of clients or recipients with a program or benefit besides, expanding the number of clients of misuse, and the quality of programs and open administrations and at last the adequacy and execution of open administrations and programs to be accomplished.

Non-financial markets including benefit quality, benefit client fulfillment, provider fulfillment, intentional exercises, and program adequacy (Mahmoud and Yusif, 2012). Organizational performance could be productivity degree of organizational fund and trade handle execution within the organization (Moon, Choi and Armstrong, 2018).

The comprehensive authority created by Fred Fiedler stated that the execution of a gather is emphatically impacted by the reasonableness of the administration fashion and the sum of control and supervision of distinctive circumstances. The Baldrige Excellence Awards (United States) in Colin Talbot (2010) said that administration incredibly impacts organizational performance. The measurements of organizational performance are organizational adequacy and quality benefit preambles (Wahab et al., 2016). Organizational performance is measured based on deals' development. Yang et al. (2013) stated that organizational performance indicators are market share, efficiency, growth, profit and productivity (Subramony et al., 2018).

\section{Research Methods}

This research used quantitative methods, based on the results to be achieved is applied research with descriptive methods. Primary data was obtained through 
questionnaires while secondary data was gained from company annual reports. The number of companies studied was 15 coal mining companies in Indonesia that had been listed. The number of samples was at least 5 times the number of indicators, where the number of indicators in this study was 26 indicators so that the minimum sample was 130 samples, therefore, the study has met the requirements because the number of respondents was 201 (Hair, 2010). The determination of reliability and validity was tested using SPSS and then the data was processed using the Structural Equation Model-Analysis of Moment Structures (SEM-AMOS) and to test the indirect effect used the Sobel Test.

\subsection{Framework Study}

The conceptual framework of this study is presented in Figure 1.

Figure 1. Conceptual Framework

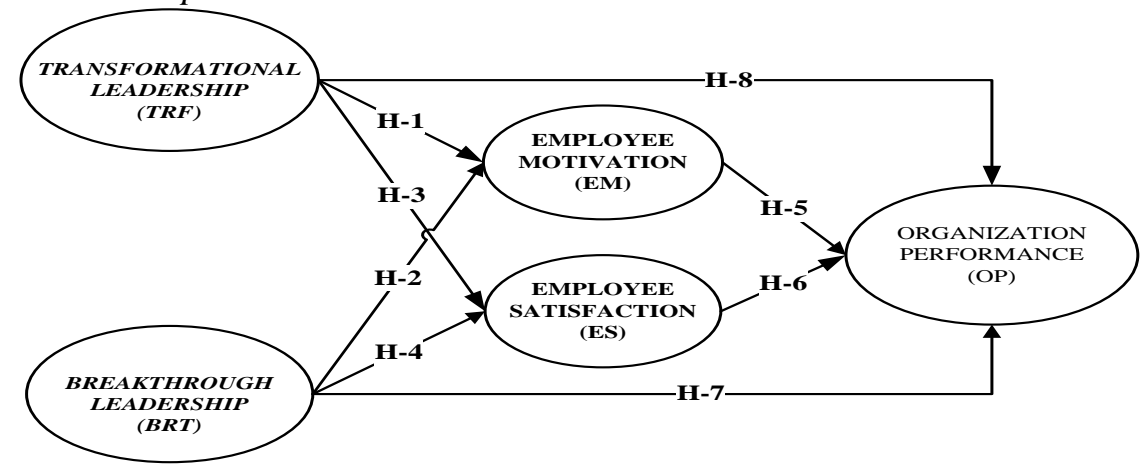

Source: Own study.

\subsection{Hypotheses}

By referring to the conceptual framework above, the author formulates the research hypotheses as follows:

H1: Transformational leadership (TRF) has an impact on employee motivation (EM).

H2: Breakthrough leadership (BRT) has an impact on employee motivation (EM).

H3: Transformational leadership (TRF) has an impact on employee satisfaction (ES).

H4: Breakthrough leadership (BRT) has an impact on employee satisfaction (ES).

H5: Employee motivation (EM) has an impact on organizational performance (OP).

H6: Employee satisfaction (ES) has an impact on organization performance (OP).

H7: Breakthrough leadership (BL) has an impact on organizational performance $(O P)$.

H8: Transformational leadership (TRF) has an impact on organizational performance $(O P)$. 
H9: Employee motivation (EM) mediates between transformational leadership $(T R F)$ with organizational performance $(O P)$.

H10: Employee motivation (EM) mediates between breakthrough leadership (TRF) with organizational performance $(O P)$.

H11: Employee satisfaction (EM), mediates between transformational leadership $(T R F)$ with organizational performance $(O P)$.

H12: Employee satisfaction (ES), mediates between breakthrough leadership (TRF) with organizational performance $(O P)$.

\section{Results and Discussion}

\subsection{Goodness of Fit Model}

The compatibility test of the basic demonstrate in SEM-AMOS examination was carried out by looking at a few goodness of fit show criteria such as chi square, probability, degree of freedom, chi square/ degree of freedom, RMSEA, GFI, AGFI, CFI. After analysing the data, we get a structure that incorporates the goodness of fit of the model: RMSEA specifications $0.020-0.080$, Chi Square, Degree of Freedom $<2.00$, GFI $>0.900$, AGFI $>0.900$, CFI $>0.900$. If the model mostly enters the criteria required then it can be declared fit (Ghozali and Fuad, 2005).

Figure 2. Result of Goodness Fit Model

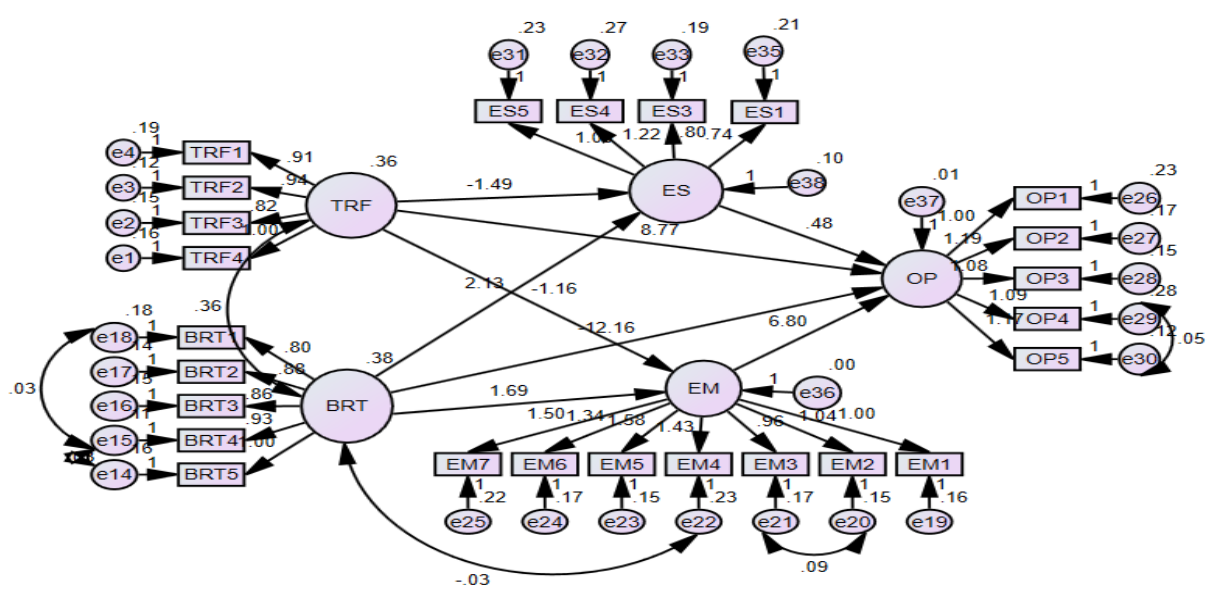

Source: Own study.

The goodness-of-fit criterion in Figure 2 requires three basic assumptions to be fulfilled in the structural equation model, namely independent data observation, respondents are taken randomly and have a linear relationship then processed in the SEM-AMOS software and produces the following output: 
Table 1. Model Fit Summary

\begin{tabular}{lcccccccccc} 
Model & CMIN & $\begin{array}{c}\text { Degree } \\
\text { of } \\
\text { Freedom }\end{array}$ & P & CMIN/DF & GFI & AGFI & RFI & CFI & RMSEA \\
\hline $\begin{array}{l}\text { Default } \\
\text { model }\end{array}$ & 412.45 & 261.00 & 0.00 & 1.58 & 0.82 & 0.78 & 0.84 & 0.95 & 0.063 \\
\hline
\end{tabular}

Source: Own study.

This research model in accordance with Table 2 has mostly entered the existing requirements so that the model is declared fit.

\subsection{Significance Test}

Significance test prerequisites are in case P-Value $<0.05$ at that point encompasses a critical impact, and the value of CR> 1.96 at that point has an impact (Table 2).

Table 2. Result of significant test for Regression Weight

\begin{tabular}{lcccc}
\hline \multicolumn{1}{c}{ Correlation Variable } & Estimate & SE & CR & P \\
\hline Transformational leadership to employee motivation & -1.164 & 0.473 & -2.459 & 0.014 \\
Breakthrough leadership to employee motivation & 1.693 & 0.470 & 3.606 & $* * *$ \\
Transformational leadership to employee satisfaction & -1.491 & 0.622 & -2.399 & 0.016 \\
Breakthrough leadership to employee satisfaction & 2.127 & 0.606 & 3.510 & $* * *$ \\
Employee motivation to organizational performance & 6.799 & 18.951 & 0.359 & 0.720 \\
Employee satisfaction to organizational performance & 0.477 & 0.202 & 2.357 & 0.018 \\
Breakthrough leadership to organizational & -12.158 & 33.843 & -0.359 & 0.719 \\
performance & & & & 0.714 \\
Transformational leadership to organizational & 8.773 & 23.907 & 0.367 & 0.719 \\
performance & & & &
\end{tabular}

Note: $* * *=P$-Value significant under $1 \%$

Source: Own study.

Results of noteworthy test based on the result of SEM (Structure Equation Model) investigation within Table 2, are as follows:

a. There is an effect of transformational leadership on employee motivation $\rightarrow$ Hypothesis 1 is accepted.

b. There is an effect of breakthrough leadership on employee motivation $\rightarrow$ Hypothesis 2 is accepted.

c. There is an effect of transformational leadership on employee satisfaction $\rightarrow$ Hypothesis 3 is accepted.

d. There is an effect of employee motivation on organizational performance $\rightarrow$ Hypothesis 4 is accepted.

e. There is an effect of employee satisfaction on organizational performance $\rightarrow$ Hypothesis 5 is not accepted.

f. There is an effect of employee satisfaction on organizational performance $\rightarrow$ Hypothesis 6 is not accepted.

g. There is an effect of breakthrough leadership on organizational performance $\rightarrow$ Hypothesis 7 is not accepted. 
h. There is an effect of transformational leadership on organizational performance

$\rightarrow$ Hypothesis 8 is not accepted.

\subsection{Sobel Test}

Hypothesis testing indirectly or by mediating variables is carried out using the method developed by Sobel and known as the Sobel test (Ghozali, 2011) stated that the Sobel test was conducted to test the strength of the indirect effect of the independent variable on the dependent. The theories utilized within the test of Sobel are as follows:

Ho: Employee motivation (EM) and employee satisfaction (ES) can intervene the impact of transformational Leadership (TRF) and breakthrough (BRT) on organizational performance $(O P)$.

Ha: Employee motivation (EM) and employee satisfaction (ES) cannot intervene the impact of transformational leadership (TRF) and breakthrough (BRT) on organizational performance $(O P)$.

If $\mathrm{p}$ value $<0.05 \mathrm{Ho}$ is accepted as and if $\mathrm{p}$ value $>0.05 \mathrm{Ho}$ is not accepted (Table $3)$.

Table 3. Sobel Test Result

\begin{tabular}{llll}
\hline \multicolumn{1}{c}{ Correlation Variable } & \multicolumn{1}{c}{$\begin{array}{c}\text { Mediator } \\
\text { Variable }\end{array}$} & P Value & Result \\
\hline $\begin{array}{l}\text { Transformational leadership (TRF) } \rightarrow \\
\text { organizational performance (OP) } \\
\text { Transformational leadership (TRF) } \\
\text { organizational performance (OP) }\end{array}$ & $\begin{array}{l}\text { Employee } \\
\text { motivation (EM) }\end{array}$ & 0.7225 & $\begin{array}{l}\text { Not effect } \\
\text { mediating }\end{array}$ \\
$\begin{array}{l}\text { Bmployee } \\
\text { motivation (EM) }\end{array}$ & 0.0925 & $\begin{array}{l}\text { Not effect } \\
\text { mediating }\end{array}$ \\
$\begin{array}{l}\text { Berformance (OP) } \\
\text { Breakthrough leadership (BRT) } \rightarrow \text { organizational } \\
\text { performance (OP) }\end{array}$ & $\begin{array}{l}\text { Employee } \\
\text { satisfaction (ES) } \\
\text { Employee } \\
\text { satisfaction (ES) }\end{array}$ & 0.7211 & $\begin{array}{l}\text { Not effect } \\
\text { mediating } \\
\text { Mediated }\end{array}$ \\
\hline
\end{tabular}

Source: Own study.

Results of Sobel Test:

a. There is a circuitous impact of transformational leadership on organizational performance through employee motivation with p-value $0.7225>0.05 \rightarrow \mathrm{H} 9$ not accepted.

b. There is a circuitous impact of transformational leadership on organizational performance through employee motivation with p-value 0.0925> $0.05 \rightarrow \mathrm{H} 10$ not accepted.

c. There is a circuitous impact of break through leadership on organizational performance through employee satisfaction with p-value 0.7211>0.05 $\rightarrow \mathrm{H} 11$ not accepted.

d. There is a circuitous impact of break through leadership on organizational performance through employee satisfaction with p-value $0.0500<0.05 \rightarrow \mathrm{H} 12$ accepted. 


\section{Conclusion}

Rapid changes to the organizational environment in the form of technological developments and human resources, requires leaders to make new breakthroughs. Transformational leadership which is currently a means of achieving effective organizational performance still needs further study to answer the changing times. Breakthrough leadership is an alternative to the new leadership figure in the current VUCA (Volatile, Uncertain, Complex, Ambiguous) era. References from the American Management Association-AMA (2018), Harvard Business School Publishing (2012) and Leadership Psychology Australia (2009) along these lines analysts utilized the breakthrough leadership measurement of the American Management Association-AMA (2018) which includes exemplary leaders, visionaries, high work standards, ability to lead, organize and guide and ability to regenerate.

The inquiries on IDX-Listed of coal mining company in Indonesia recorded appear that transformational leadership and breakthroughs have a critical impact on employee motivation and employee satisfaction but do not straightforwardly influence organizational performance. Employee satisfaction intercedes the impact of breakthrough leadership on organizational performance but does not intercede transformational leadership on organizational performance. Employee motivation does not intercede transformational leadership and breakthrough on organizational performance. Priority fulfillment of employee satisfaction starts from need fulfillment, discrepancies, value attainment, equity, and dispositional / genetic component. The novelty in this point of study is providing new concepts in the framework of leadership research and to construct and enhance alternative research dimensions.

Managerial implications in this study are in order to increase organizational performance through increasing employee satisfaction, things that must be done to increase employee satisfaction, company leaders must prioritize the following: First, the company leader must apply a balance in providing compensation and income in accordance with the position level and job risks, second company leaders must make selection and placement of employee in accordance with their passion, third, company leaders must be able to re-evaluate the appropriate reward to employees who successfully achieve the targets set so that employee satisfaction is met, fourth the leader of the company must have a mission, determination and concrete action to meet all the needs of employees.

This study proves that the type of leadership directly has a positive and significant effect on job satisfaction and indirectly affects organizational performance through the mediating variable of employee satisfaction on just leadership breakthroughs, so with the findings of this study, the priority that the company must do is an open coal mining company (IDX-Listed) must not worry that its position will be replaced by its subordinates so that it must create new leaders. Second changes in technology, 
environment and human resource behavior are so fast that it requires flexibility of company leaders in transforming the company's vision quickly, especially in General Manager and Director level. Third, the leader of an open coal mining company in Indonesia (IDX-Listed) must continuously improve existing work standards by always making continuous improvements to higher work standards both in organizational performance, especially occupational safety, occupational health, work environment, finance, engineering, production and logistics so as to increase employee motivation. Fourth, the leadership in all lines starting from Supervisors, Section Heads, Superintendent, Managers, General Managers and Directors provide exemplary in terms of work and good attitudes in decision making.

\section{References:}

Abasilim, U.D., Gberevbie, D.E., Osibanjo, A. 2018. Canonical analysis of perceived leadership styles and employees' commitment in Nigeria. In ECMLG 2018 14th European Conference on Management, Leadership and Governance, p. 317. Academic Conferences and publishing limited.

Al Haj, A. 2017. Leadership Styles and Employee Motivation in Qatar Organizations. Walden Dissertations and Doctoral Studies, 3380.

Ali, N.N.K., Tang, S.Y. 2016. Does Multiple Leadership Styles Mediated by Job Satisfaction Influence Better Business Performance? Perception of MNC' Employees in Malaysia. In SHS Web of Conferences, Vol. 23, 02005. EDP Sciences.

Akinola, G.O., Akinbobola, A.O., Agorzie, C.J., Okotoni, C.A., Ojedele, M.I. 2014. Employee Motivation and Organizational Performance of Quoted Firms in the Nigerian Food, Beverage and Tobacco Industry. Global Journal of Commerce and Management Perspective, 3(4), 220-227.

Amin, D. 2016. The Role of Transformational leadership on Organizational Performance in Kenya: A Case Study of National Bank of Kenya. Doctoral dissertation, United States International University-Africa.

Aunjum, A.H., Abbas, G., Sajid, M. 2017. Transformational Leadership and Employee Motivation in Banking Sector of Pakistan. Advances in Economics and Business, 5(9), 487-494.

Bass, B.M. 1999. Two decades of research and development in transformational leadership. European journal of work and organizational psychology, 8(1), 9-32.

Colquitt, J.A., Rodell, J.B. 2011. Justice, trust, and trustworthiness: A longitudinal analysis integrating three theoretical perspectives. Academy of Management Journal, 54(6), 1183-1206.

Diratama, I. 2018. Analisis Prediksi Kebangkrutan pada Perusahaan Pertambangan yang Terdaftar di bursa Efek Indonesia Tahun 2014-2016. Jurnal Akuntansi, 6(1).

Dowling, J., Pfeffer, J. 1975. Organizational legitimacy: Social values and organizational Jobehavior. Pacific sociological review, 18(1), 122-136.

Dugguh, S.I., Dennis, A. 2014. Job satisfaction theories: Traceability to employee performance in organizations. Journal of business and management, 16(5), 11-18.

Emeka, N., Amaka, O., Ejim, E.P. 2015. The Effect of Employee Motivation on Organizational Performance of Selected Manufacturing Firms in Enugu State. World Journal of Management and Behavioural Studies, 3(1), 1-8.

Gera, L., Vis, D., Michael, U. 2002. Top management, company directors and corporate control. Handbook of strategy and management, 232. 
Ghozali, I. 2017. Model Persamaan Struktural: Konsep dan Aplikasi dengan Program Amos 24 Edisi 7. Semarang: Universitas Diponegoro.

Gjoka, X., Rogler, K., Martino, R.A., Gantier, R., Schofield, M. 2015. A straightforward methodology for designing continuous monoclonal antibody capture multi-column chromatography processes. Journal of Chromatography A, 1416, 38-46.

Goleman, D., Collingwood, H., Peace, W., Pagonis, W., Tedlow, R., Peters, T., Jones, G. 2001. Harvard business review on breakthrough leadership. Harvard Business Press.

Hair, J.F. 2015. Essentials of business research methods. ME Sharpe.

Hamdam, H., Pakdel, A., Soheili, S. 2012. The study of board's remuneration and its relationship with accounting indicators for firm's performance evaluation (evidence from Tehran Stock Exchange). Australian Journal of Basic \& Applied Sciences, 6(10), 403-408.

Ho, V.T., Dinh, T.L., Vu, M.C. 2016. Transformational and transactional leadership styles and employees' job satisfaction in Vietnamese local companies. International Review of Management and Business Research, 5, 938-950.

Jimad, H., Maarif, M.S., Affandi, M.J., Sukmawati, A. 2020. Leadership Strategy of State University Public Service Agency to Increasing Organizational Performance in Indonesia. International Business and Accounting Research Journal, 4(1), 23-36.

Joshi, A.S., Tiwari, A., Tiwari, G.N., Dincer, I., Reddy, B.V. 2009. Performance evaluation of a hybrid photovoltaic thermal (PV/T)(glass-to-glass) system. International Journal of Thermal Sciences, 48(1), 154-161.

Katou, A.A. 2015. Transformational leadership and organisational performance: Three serially mediating mechanisms. Employee Relations, 37(3), 329-353.

Lee, M.T., Raschke, R.L. 2016. Understanding employee motivation and organizational performance: Arguments for a set-theoretic approach. Journal of Innovation \& Knowledge, 1(3), 162-169.

Leksono, N. 2018. Pembangunan, pluralitas, dan era disrupsi. In Seminar Dies Natalis XXV Fakultas Sastra, Multikulturalisme dalam Perspektif Pendidikan Humaniora di Era Disrupsi. Yogyakarta: Universitas Sanata Dharma.

Luthans, F., Doh, J.P. 2012. International management: Culture, strategy, and behaviour. New York, McGraw-Hill.

Mahmoud, M.A., Yusif, B. 2012. Market orientation, learning orientation, and the performance of non-profit organisations (NPOs). International Journal of Productivity and Performance Management.

Marn, J.T. 2012. The impact of transformational leadership practices on job satisfaction of PHEI lecturers. Journal for the Advancement of Science and Arts, 3(2), 26-39.

McShane, S., Glinow, M.A.V. 2017. Organizational behaviour. McGraw-Hill education.

Mbambo, L.E. 2017. An analysis of corporate governance in state-owned enterprises (SOEs) in compliance with the King Code principles of good governance. Doctoral dissertation, University of the Free State.

Moon, Y.J., Choi, M., Armstrong, D.J. 2018. The impact of relational leadership and social alignment on information security system effectiveness in Korean governmental organizations. International Journal of Information Management, 40, 54-66.

Mujkić, A., Šehić, D., Rahimić, Z., Jusić, J. 2014. Transformational leadership and employee satisfaction. Ekonomski vjesnik: Review of Contemporary Entrepreneurship, Business, and Economic Issues, 27(2), 259-270.

Nanjappa, V., Thomas, J.K., Marimuthu, A., Muthusamy, B., Radhakrishnan, A., Sharma, R., Jhaveri, B.N. 2014. Plasma Proteome Database as a resource for proteomics research: 2014 update. Nucleic acids research, 42(D1), D959-D965. 
Newstrom, J. 2014. Organizational behavior: Human behavior at work. McGraw-Hill Higher Education.

Rawat, S.R. 2015. Impact of transformational leadership over employee morale and motivation. Indian Journal of Science and Technology, 8(S6), 25-34.

Resvani, 2017, Tambang untuk negeri, Fisrt edition, Bhuana Ilmu Populer, Jakarta.

Resky, R., Kuncoro, E.A. 2012. Pengaruh Gaya Kepemimpinan terhadap Motivasi dan Dampaknya terhadap Kinerja Sumber Daya Manusia. Binus Business Review, 3(1), 400-412.

Sari, O.R., Susilo, H. 2018. Pengaruh Kepuasan Kerja Terhadap KinerjaKaryawan Dengan Organizational Citizenship Behavior Sebagai Variabel Intervening (Studi Pada Karyawan Ptpn X- Unit Usaha Pabrik Gula Modjopanggoong Tulungagung). Jurnal Administrasi Bisnis, 64(1), 28-35.

Sappe, S., Rante, Y., Tuhumena, R., Bharanti, B.E. 2016. Effect of Leadership on Employee's Performance Mediated by Cultural Organization, Work Commitment and Motivation. Journal of Economics and Behavioural Studies, 8(2(J)), 101-107.

Saputra, R.C.A. 2019. Pengaruh Gaya Kepemimpinan Terhadap Kinerja Karyawan Pada Pt. Loa Haur Energi (Minning Contractor) Di Sungai Payang Loa Kulu Kab. Kutai Kartanegara Kalimantan Timur. Administrasi Publik, 2(2), 955-968.

Sarwani, S., Sunardi, N. 2019. Analisis Penggunaan Altman Z-Score untuk Mengetahui Potensi Kebangkrutan Industri KonstruksI (BUMN) di Indonesia Tahun 2013-2017. In Proceedings, Vol. 1, No. 1.

Subramony, M., Segers, J., Chadwick, C., Shyamsunder, A. 2018. Leadership development practice bundles and organizational performance: The mediating role of human capital and social capital. Journal of business research, 83, 120-129.

Talbot, C. 2010. Theories of performance: Organizational and service improvement in the public domain. Oxford University Press.

Triraharjo, J., Aima, H., Sutawijaya, A. 2019. The Effect of Servant Leadership and Breakthrough Leadership on Organization Performance with Employee Satisfaction as Intervening Variable at IDX-listed (Indonesia Stock Exchange) Coal Mining Companies in Indonesia. International Review of Management and Marketing, 9(3), 166.

Wahab, S., Rahmat, A., Yusof, M.S., Mohamed, B. 2016. Organization performance and leadership style: Issues in Education Service. Procedia-Social and Behavioural Sciences, 224, 593-598.

Wijaya, I.K. 2018. Pengaruh Kepuasan Kerja Terhadap Kinerja Karyawan CV Bukit Sanomas. Agora, 6(2). 